\title{
Trust is knowing that... The subjective meanings and senses of experience-based foundations of trust of students with intellectual disabilities
}

\author{
Teresa Żółkowska ${ }^{1}$ and Karolina Kaliszewska ${ }^{2}$ \\ ${ }^{1}$ Institute of Pedagogy, University of Szczecin, Poland \\ ${ }^{2}$ Institute of Psychology, University of Szczecin, Poland
}

\begin{abstract}
HOW TO CITE:
Żółkowska, T., Kaliszewska, K.
\end{abstract} (2021). Trust is knowing that...

The subjective meanings and senses of experience-based foundations of trust of students with intellectual disabilities. International Journal of Special

Education, 36(1), 121-128 CORRESPONDING AUTHOR:

Teresa Żółkowska; teresa.zolkowska@usz.edu.pl

DOI:

https://doi.org/10.52291/ ijse.2021.36.12

\section{COPYRIGHT STATEMENT:}

Copyright: () 2021 Authors. Open access publication under the terms and conditions of the Creative Commons Attribution (CC BY) license (http://creativecommons. org/licenses/by/4.0/).

\section{ABSTRACT}

Trust refers to daily life facilitating factors, to social integration, to a sense of security or quality of life. So far, there have been no studies analysing the trust of students with intellectual disabilities. The analysis of trust of young persons with intellectual disabilities was not attempted. Therefore, a question was formulated: what meanings and senses do students with these disabilities assign to their experiences of the foundations of trust? The study features qualitative research interviews (in-depth and non-structured). The theoretical and empirical assumptions apply the interpretive/constructivist paradigm and phenomenological-hermeneutic perspective based on Alfred Schütz's social theory. The empirical material was obtained based on 11 interviews conducted with students with mild intellectual disabilities of 6th -8 th grades of special needs comprehensive school. The basis for trust is everyday knowledge manifested in: the knowledge about the essence of trust, knowledge of the study's participants - their skills and capabilities, the cause that leads to a specific result. Knowledge as the foundation of trust is common and non-reflective, but also authentic and dynamic, revealing ways of coping with everyday life. The meanings and senses assigned to objects, humans and relationships are not a direct representation of the social world, but they constitute in fact the way of life of the subjects.

Keywords: intellectual disabilities, social theory, Alfred Schütz, trust 


\section{INTRODUCTION}

Trust is recognised as one of the factors of interpersonal relations in social situations (Źółkowska, 2014). Trust is a subject of studies in the areas of various scientific disciplines: sociology, psychology, pedagogy, economics, political science, etc. It is analysed in terms of the concept, structure, bases, function and the creation of culture of trust (Sztompka, 2007). To-date research has been focused on trust of "fully able" people, without any additional attributes in the form of dysfunctions, whether psychological or physical. What is more, studies on trust of students with intellectual disabilities, including those with mild intellectual disabilities, have not been attempted.

The subject of the research was the experiences of students with intellectual disabilities and, in particular, the subjective meanings and senses assigned by them to their own experience-based foundations of trust and their experiences of culturally defined structures and practices of everyday life. Foundations of trust, whereby trust is recognised as the relationship with other people, are understood here as certain knowledge regarding a particular person whom one intends to trust. The said knowledge can either be true or false, correct or incorrect. The proper attribution of trust is more likely to increase with growing amount and variety of information about another person (Sztompka, 2007, p. 152).

\section{THE OBJECTIVES OF THE RESEARCH}

An objective of the research was to recognize, understand and describe the subjective meanings and significance attributed by students with mild intellectual disabilities to their experiences of trust and to interpretively read the hidden meanings and significance of experiences of cultural structures and practices of everyday life of the participants of the research as sources of constructing experiences of trust (the expectations). Additionally, the study intends to point to the rules, theoretical basis of the cultural construction of the experience of trust in the tested group to specialists, parents, and others who work with persons with moderate intellectual disabilities.

The following questions have been identified: 1) What subjective meanings and senses were assigned to the experience-based foundations of trust by students with intellectual disabilities who participated in the research? 2) Which subjective meanings and senses assigned to the structures and practices of culturally-oriented everyday reality, in which the experiences of trust occur, can be found in statements provided by the respondents?

The questions are formulated according to the interpretive/constructivist paradigm and the phenomenological-hermeneutic perspective based on the social theory by Alfred Schütz (2008), both in terms of how trust is defined, assigning meanings to the experience-based foundations of trust, as well as in terms of covering the hidden meanings and senses assigned by students to the cultural context in which their trust experiences occur. This was founded on the assumption that the creation of meanings and senses is determined by the context in which the main role is played by culturally-oriented structures and practices of everyday life, rooted in everyday reflection of society on disability, in power relations as well as the established and "the only fair" social order.

In defining the subject of the study, I assumed that the basic criterion for selecting research group was not the degree of intellectual disabilities, but the fact that a person has an intellectual disability as well as the age and social status of the participants (Borowska-Beszta, 2013). In fact, it was assumed that the subject of research is not intellectual disabilities as such, but the experiences of persons invited to the study whose denomination, way of functioning and experiences are constructed by the socio-cultural practices of everyday life. Therefore, the interpretation of the results excluded the level of intellectual development and the adaptive behaviours. (Schlalock et al., 2010)

\section{METHODS}

\section{Research project}

The study was conducted using qualitative research interview (unstructured in-depth interview) and participant observation (Fontanta, Frey, 2009, p. 95). This was founded on the assumption that qualitative research interview is a setting where knowledge is jointly constructed by interviewer and interviewee (Kvale, 2004, pp. 60-62). The knowledge created in the interviews was set off against the empirical phenomenological-hermeneutic perspective.

The research was conducted in 2020 through professional and private contacts with people with intellectual disabilities who live in a special needs comprehensive school and with their families. 
The concept of the research and the recruitment methods, research tools, and then the analysis of the research results were consulted with the Ethics Committee operating at the Polish Association for Persons with Intellectual Disability in Szczecin.

\section{METHODS OF RESEARCH. Trustworthiness and Credibility}

\section{Semi-structured interviews}

Interview questions were general in nature, their form and content adjusted to individual capabilities. All interviews were conducted individually. Firstly, I obtained an informed consent to participation. I only interviewed persons who were interested in the subject and were willing to participate in the research. All respondents were assured about the confidentiality of their data. I also took care to ensure that there would be no consequences of participation for the respondents on the part of their parents, assistants, therapists, physiotherapists, job coaches, facility management as well as peers. The research tools and concept, and the further analysis of the results have all been consulted with the Ethics Committee at the Polish Association for Persons with Intellectual Disability in Szczecin and conforms with the Declaration of Helsinki. Personal data have been coded and changed. The only information kept was the age and the data on intellectual disabilities. Furthermore, the data on the facilities was coded and disguised, leaving only the facility type (SHCC, OTW, VDC, SWH, SH, IL) and family placement (FH, IL).

I treated respondents as subjects having their own opinions and views, persons who can describe their experiences and interpret their actions, actions of others or refer to the experiences of their social world. Upon encountering a problem of verbalising thoughts, I repeated the issues in order to be sure that both me and the topic were properly understood. In line with the hermeneutic phenomenology perspective, I attempted to have an unbiased attitude.

The answers were recorded and then transcribed. Due to the changes in the data format (Gibbs, 2011, p. 36), in order to ensure accurate and faithful interpretation, all interpretations of the transcribed data have been cross -checked with the interpretation contained in the original recording. I decided that I would neither transcribe the change of emphasis, tone of voice, or overlapping responses, nor indicate the length of pauses, but only use dots to denote them (“...”).

The answers were interpreted using a phenomenological-hermeneutical perspective based on the qualitative data analysis developed by Kvale (2004). The technique allows for such arrangement of empirical data which combines phenomenological and hermeneutic analyses. This is possible due to the fact that the sense interpretation technique allows us to go beyond the explicit meaning of the text to a more in-depth interpretation. It allows us to go beyond the literal meaning of what is said directly in order to develop structures and relationships of hidden meanings and senses.

I have based the organization of the data for analysis on various tactics of the extraction of meaning from qualitative texts (Miles, Huberman, 2000, pp. 252-253) used in the following stages: a) getting acquainted with the research material, structuring and clarifying it; b) noticing patterns of data; c) recognising similarity; d) grouping, based on utterances' meanings; e) generalizing and specifying forms, $\mathrm{f}$ ) adopting and naming topics and then topic threads - general and then the collateral; g) searching for relations between particular threads and thematic versions - the field of their relationship constituting the resulting area of exploration.

The statements were analysed both individually and holistically. The approval and naming of topics, topic threads and thematic versions in the research material was related to the analysis in the terms of part-to-whole and whole-to-part ratios. The arrangement of empirical data was descriptive and structural. The descriptive dimension described the statements and what they concerned, i.e. the general meanings and senses assigned to the experience-based foundations of trust and the experiences of cultural structures and practices of everyday life. On the other hand, the structural dimension allowed for the identification of the structure of data patterns as well as the relationships between particular topics, topic threads and thematic versions (Mils, Huberman, 2000). The results were verified using data triangulation obtained by qualitative research interview and participant observation. I opted for data sources' triangulation (verbal and non-verbal) (Gibbs, 2011, p.167). The accuracy of the analyses was assured by the constant comparative method (Gibbs, 2011, p.170). Reliability on qualitative research related to consistency of research results (Kvale, 2004, p.239) was achieved as a result of multiple comparisons 
(Gibbs, 2011, p.175) carried out during transcription, arrangement and analysis of research material and preparation of a description. Additionally, the interpretation was based on the criterion-related validity of results.

\section{RESULTS}

In phenomenological-hermeneutic analysis, two ways of presenting the examined reality are used. The first one includes the statements of respondents subjected to a phenomenological-hermeneutic reading and the ensuing interpretation which reveals the senses and meanings of experiences and the message hidden in the direct statements. The second one is my own reading of meanings and senses contained in the statements, and my interpretation of these meanings.

Trust means knowing that ... will help ... will not deceive ... will never cheat

Considering the complexity of trust and that it is the trust of adults with intellectual disabilities that is being analysed, it is appropriate to examine this concept in the colloquial language used by the respondents. Built within the semantic field of the topic: the concept of trust, the topic threads and thematic versions have been saturated with empirical data by selecting subsequent cases. Exceeding the saturation threshold, construed as theoretical saturation, occurred after a dozen or so statements. Subsequent voices would duplicate information and therefore, did not enrich the existing theoretical content of the reconstruction.

The topic of the concept of trust is related to the main topic thread referred to as: trust is knowledge. This main topic thread turned out to be related to the collateral thread: the aspects of knowledge about trust, which was defined by three thematic versions reflecting various aspects of knowledge of my respondents in terms of foundations of trust.

\section{The aspects of knowledge about the founda- tions of trust by research participants}

To determine the semantic field of this main topic thread - trust is knowledge - I selected the most typical, repetitive and common content containing the propositional knowledge expressed by the words: (he/she) knows, (I) know, knowledge, (to) know. As emphasised by Marian
Przelęcki, the knowledge of the propositional content of one's own attitudes involves an attitude (which is independent of those beliefs or intentions) towards other people (public background of knowledge) and non-linguistic events and objects (Przełęcki, 1997).

The answers taking the form of trust is knowledge have revealed some specific ways of constructing senses and meanings of the experienced foundations of trust, which I recognise as a collateral thread referring to the aspects of knowledge about trust. The aspects of knowledge refer to the differences resulting from various perceptions of the "dimensions" of reality (Niżnik, 1998, p. 166).

As a result of the arrangement of empirical data, the collateral thread of aspects of knowledge about trust has been defined by three thematic versions, i.e.: trust as an aspect of knowledge about the essence of trust, trust as an aspect of knowledge on what cause is responsible for a given effect and trust as an aspect of knowledge about the research participants themselves - their talents, skills and abilities.

Among the statements belonging to the thematic version: trust as an aspect of knowledge about the essence of trust, the following were considered typical:

Arkadiusz (47, VDC/IL): It means trusting another person... knowing that one won't say anything;

Wanda (43, SHCC/FH): To know that ... the other person won't lie;

Beata (36, VDC/FH): When you know that the other person will keep a secret;

Justyna (36, FH): Not betraying ...secrets;

Dominika (25, OTW/FH): ...When I can tell them everything;

Marzena (38, VDC/FH): When one keeps someone else's secrets;

Urszula (40, VDC/FH): Only a friend can be trusted ...sad but true,

Stawomira (49, SWH): To know that they are, uh, ... attached to us;

Irena (55, SWH): To know that someone will be honest;

Mirosława (48, FH.): They will help...;

Rafał (24, OTW/FH): Someone who is, uh, ... a good person;

Weronika (37, VDC/SH): Times are difficult, and people cheat on each other, and they do other stuff; 
Lucyna (41, SWH): It's like having a friend ...whom, uh, you can trust;

Wincent (50, SHCC/FH): It's when someone promises you something, ... and then they keep their word;

Dariusz (58, FH): When you can trust someone ...trust another person.

The above-mentioned thematic version included such meanings such as: trusting someone or knowing that someone. Therefore, according to the respondents, the essence of trust is the knowledge that a trustworthy person is someone who meets their expectations regarding faithfulness, honesty, protectiveness, care or responsibility, as in the example of Irena $(55, \mathrm{SWH})$ who emphasised that it is important "to know that someone will be honest" and Wanda (43, SHCC /FH) who said you can trust a person who "won't lie," or in the words of Sławomira $(49, S W H)$ indicating that we trust the people of whom we know "that they are, uh, ...attached to us."

Other versions of meanings and senses of knowledge aspects regarding the essence of trust are those that relate to the meanings assigned to knowledge or trusting something, some value, norm, principle, "the obvious" taken from the structures of the social world. Wincent (50, $\mathrm{SHCC} / \mathrm{FH}$ ) believes that trust is "when someone promises you something, ... and then they keep their word." For Dominika (25, OTW/FH), trust is a sense of security because when you trust people, you "can tell them everything." Others, including Beata (36, VDC /FH), stressed the importance of keeping secrets. While attempting to discover what "a secret" is, I did not receive any extended explanations. In general, my respondents would repeat the term claiming that it is about secrets or clarifying that it is about secrets/matters important to them. A good example of this will be the response from Beata (36, VDC /FH): "you know, they are secrets... and all that stuff." Only a few respondents (higher-functioning persons) indicated that secrets may concern the interest in the opposite sex or that these may be issues related to some failure in life.

Referring to the field of collateral thematic thread, the aspects of knowledge about trust, yet another thematic version can be distinguished. Statements regarding trust as an aspect of knowledge on what cause is responsible for a given effect are illustrated by the following utterances:
Danuta (47, FH): It means that you trr... trust someone and know that, uh, they will be good;

Tatiana (43, SHCC/FH): When I trust, I know ... someone.... will not betray me;

Alicja (62, FH): When you trust... she will be kind and good;

Iga (65, OTW/FH): It's when you agree to meet someone, and he says he will be there;

Konstancja (46, OTW/FH): To know that they.... will not tell my secrets... to anyone;

Magdalena (50, SWH): When you know you can tell... someone;

Elżbieta (30, VDC /FH): Trust is when you aren't afraid that... someone will do something to you, they are simply... good to you;

Bogumil (36, VDC/IL): It means that you can trust someone, for example, if someone wanted to take you to a restaurant then that person ... must be trusted, they must be ... well ...nice, chatty, calm... then it's someone you can trust.

The above statements reflect the principles and values found by the respondents in everyday life and which, according to them, are significant for the experiences of trust to occur. In their case, these are the rules defining how to function in order to trust and be trusted. According to them, trust can be assigned only to a person who is guided by values such as: goodness, reliability, sensibility, responsibility or credibility. Based on the principle that a certain cause is responsible for a given effect, the respondents believe that trust can be bestowed only upon someone who respects the patterns and values of their world and life and exhibits appropriate behavioural traits.

In terms of behavioural traits important in the context of trust, I have encountered, among others, the following opinions in the research material: Danuta (47, FH) stresses being good, Alicja (62, FH) emphasizes being good and kind, Tatiana (43, SHCC/FH) and Konstancja $(46, \mathrm{OTW} / \mathrm{FH})$ point to honesty and keeping the word, while Bogumil (36, VDC/IL) focuses on responsibility. These characteristics indicate the importance of social patterns and standards as factors constructing their experience of trust. What is disturbing, however, is 
the content of these patterns and norms, since emphasising such features as "good" and "kind" suggests that the circles of socialisation distort experiences by perpetuating categories characteristic of earlier stages of development. In other words, people who are significant to them, the representatives of social support environments - treat them as children and define them in terms of duties. Meanwhile, my respondents - as shown by their answers - reproduce such imposed social representations as known, recognised and obvious.

The above-mentioned senses and meanings of experiences are also related to the third thematic version trust as an aspect of knowledge about the research participants themselves - their talents, skills and abilities. As presented above, the respondents efficiently mastered both reading and expressing the principles of everyday life regarding values and behaviours of people who can be trusted. The knowledge of these properties also allows to recognise their own capabilities that make others trust them.

Excerpt from an interview with Maciej (33, VDC, FH)

T.: Do you trust yourself?

Maciej: I do.

T.: Why?

Maciej: I put books... I put everything into a drawer;

Maciej: I am dressed, clean sweater on my own, put pants on, clean;

T. Why can you be trusted?

Maciej: good... smart... likeable, punctual, I listen, don't shout,

The position presented above seems to indicate that my respondent knows and acknowledges the characteristics that make one trustworthy. He/she emphasises the importance of proper behaviour, obedience, but also kindness, politeness, being helpful to others. $\mathrm{He} /$ she reads and applies patterns and rules defining his social existence, principles imposed by cultural structures and practices prevalent in culture and power relations. By revealing the subjective senses and meanings of experience, it can be argued that the study participants acknowledged the „silent” rules of social functioning. The power of the dominant discourse, which portrays disability as an object requiring constant care and supervision, seems to introduce and induce my respondent to internalize and apply a system of socially accepted norms, principles and rules of everyday life.

\section{DISCUSSION AND CONCLUSIONS}

To conclude, it can be argued that the above-presented readings of senses and meanings included in the three versions of the collateral aspect of knowledge about trust seem to be rooted in everyday life. The senses and meanings of these aspects of knowledge about trust seem to come from the persons who support the respondents, whom the latter accept and have feelings for. These persons include their parents, assistants, caregivers, therapists, rehabilitators, coaches, people they live with (Cytowska, 2012, Woynarowska 2010, Krzemińska, 2012, Żyta, 2011). As the empirical material shows, the knowledge about the foundations of trust is accepted in a passive, pre-reflective way. The reason may be the respondents' high susceptibility to suggestion. It is demonstrated in the way they acquire knowledge from others due to their limited amount of experience and information to verify or establish their own position (Zasępa, 2017). Another reason may be that the knowledge adopted in their daily activities gives them a sense of security, the comfort of a peaceful, safe life.

My respondents recognise the rules that guide people in their environment and accept them as their own. The knowledge of their significant others is recognised as the only true, obvious, and undisputed one. In relation to the above, decisive voices such as that of Tadeusz, arise (49, SWH): You got to know... there is nothing to talk about... you just got to know it...

The analysis of the research material shows that the participants, just like others, build their knowledge by repeating their experiences, using the interpretations they encountered in the process of socialisation. They are faithful to the experience gained earlier.

The responses are marked by limited, unidirectional opinions. They are also filled with stereotypes of an ideal man, a person without defects, characterised only by positive features socially recognised as valuable. Meanings and senses are attributed to some superficial, undifferentiated relationships with others. When portraying an ideal man, the respondents use "ought" words, indicating what principles one should follow. Such portrayal of a person appears to be limited, unreal and deceptive as it encloses my respondents within a space of limited, schematic and socially permissible meanings and senses of experiences. The discussed way of adopting meanings and senses can be described as a hidden programme of 
the world of life. In my opinion, the quoted statements reveal areas indicating a reproduction of a certain social order.

Here, I refer to a sanctioned placement of the intellectually disabled within the dominant culture as dependent and adhering to social norms and rules and requiring continuous repetition of a given social order. The personal message from the respondents clearly reflects the social meanings and senses prevalent in social consciousness and defining their social image. Considered weak and dependent, they became subordinated to social expectations and adapted to live in accordance with the rules of prevailing social order. The subjective message also reveals that they adopt the view of themselves as an object of normative interactions from the dominant culture and they submit themselves to such vision, way of thinking and addressing them. Allowing for such passivity, subordination, correction of qualities, competences or lifestyles, they passively submit to these culturally-oriented structures and practices to prove being trustworthy. Submission, passive adaptation and recognising as true of what culture has imposed on them, also shapes their identity. By emphasising the importance of such qualities as being good, kind and obedient, they construct their identities based on the senses they adapt from their significant others in their life. By internalising the senses and meanings imposed on them, they try to adapt to their world of life. However, as argued above, adaptation may also be negative. It can be expressed through passivity, submission, subordination, accepting the current circumstances imposed by the dominant culture and power relations. Power relations deny the disabled the opportunity to choose, decide for oneself, build one's own identity based on a personal view of the world and put them in an excluded position, even when one strives to fight for personal senses and meanings.

The empirical material provided descriptions of the meanings and senses of the concept of trust and enabled the identification of hidden knowledge. The respondents' knowledge is colloquial and non-reflective, but also authentic, dynamic and revealing the adopted course of actions, ways of coping with everyday life, within the network of various relations and structures of their social world. Despite a specific placement in the cultural context, my respondents remain active participants in everyday reality. The participants perceive this reality through the prism of its beliefs and knowledge and act in accordance with said beliefs about the laws, principles and rules of such reality. In this way, these persons construct their world - an understandable and safe everyday life. The meanings assigned to objects, humans and relationships are neither external to the social world, nor are they a direct representation of that world, but they are the way of life of the respondents.

\section{ACKNOWLEDGEMENT}

None.

DISCLOSURE STATEMENT

No potential conflict of interest

was reported by the authors.

FUNDING: None. 


\section{REFERENCES}

Borowska-Beszta, B. (2013). Niepełnosprawność w kontekstach kulturowych i teoretycznych. Kraków: Oficyna Wydawnicza Impuls. Cytowska, B. (2012). Trudne drogi adaptacji: wątki emancypacyjne w sytuacji dorosłych osób z niepełnosprawnością intelektualną. Kraków: Oficyna Wydawnicza Impuls.

Fontana A., Frey J.H. (2009). Wywiad. Od neutralności do zaangażowania. In: N.K. Denzin, Y.S. Lincoln (red.), Metody badań jakościowych. Warszawa: WN PWN, vol. 2, pp. 81-127.

Gibbs, G. (2011). Analizowanie danych jakościowych. Warszawa, WN PWN.

Glaser, B. G., Strauss, A. L. (2009). Odkrywanie teorii ugruntowanej. Strategie badania jakościowego. Kraków, NOMOS.

Kijak, R. (2017). Dorośli z głębszą niepełnosprawnością intelektualną jako partnerzy, małżonkowie i rodzice. Kraków: Oficyna Wydawnicza Impuls.

Krzemińska, D. (2012). Język i dyskurs codzienny osób z niepełnosprawnością intelektualną. Kraków: Oficyna Wydawnicza Impuls.

Kvale, S. (2004). InterViews. Wprowadzenie do jakościowego wywiadu badawczego. Białystok: Trans Humana.

Miles, M.B., Huberman, A.M. (2000). Analiza danych jakościowych. Białystok: Trans Humana.

Niżnik, J. (1998). „Potoczność” jako kategoria teoretyczna. In: A. Jawłowska (red.), Kategoria potoczności. Warszawa: Instytut Kultury, pp. 159-165.

Przełęcki, M. (1997). Przekonania jako przedmiot oceny moralnej. Filozofia Nauki 5 (4), pp. 5-14.

Rzeźnicka-Krupa, J. (2007). Komunikacja - edukacja - społeczeństwo (wersja papierowa).

O dyskursie dzieci z niepełnosprawnością intelektualną. Kraków: Oficyna Wydawnicza Impuls.

Schalock, R.L. et al. (2010). Intellectual Disability. Definition, Classification and System Supports. Washington: AAiDD.

Schütz, A. (2008). O wielości światów. Kraków: Zakład Wydawniczy NOMOS.

Sztompka, P. (2007). Zaufanie. Fundament społeczeństwa. Kraków: Wydawnictwo Znak.

Woynarowska, A. (2010). Niepełnosprawność intelektualna w publicznym i prywatnym dyskursie. Kraków: Oficyna Wydawnicza Impuls.

Zasępa, E. (2017). Osoba z niepełnosprawnością intelektualną. Kraków: Oficyna Wydawnicza Impuls.

Żółkowska, T. (2014). Zaufanie. Szkice teoretyczne. Warszawa: WN PWN.

Żyta, A. (2011). Życie z zespołem Downa, Narracje biograficzne rodziców, rodzeństwa i dorosłych osób z zespołem Downa. Kraków: Oficyna Wydawnicza Impuls. 